\title{
Novel Use of Silymarin as Delayed Therapy for Acetaminophen-Induced Acute Hepatic Injury
}

\author{
Desmond Kwok-Po Hau ${ }^{\mathrm{a}}$ Raymond Siu-Ming Wong ${ }^{\mathrm{b}} \quad$ Gregory Yin-Ming Cheng ${ }^{\mathrm{b}}$ \\ Wai-Yeung Wong ${ }^{c}$ See-Wai Tong ${ }^{b}$ Kit-Wah Chan ${ }^{b}$ Alexander Kai-Man Leung ${ }^{a}$ \\ Guo-Yuan Zhu ${ }^{a}$ Paul Bo-San Lai ${ }^{\mathrm{e}}$ Fung-Yi Lau $^{\mathrm{b}}$ Chung-Hin Chui ${ }^{\mathrm{b}, \mathrm{d}}$ Roberto Gambari ${ }^{\mathrm{f}}$ \\ David Wan-Fun Fong ${ }^{\mathrm{a}}$ \\ ${ }^{a}$ Research and Development Division, School of Chinese Medicine, Hong Kong Baptist University, \\ ${ }^{b}$ Department of Medicine and Therapeutics, Prince of Wales Hospital, The Chinese University of Hong Kong, \\ ${ }^{\circ}$ Department of Chemistry, Hong Kong Baptist University, \\ ${ }^{d}$ Institute of Textiles and Clothing, The Hong Kong Polytechnic University, \\ ${ }^{\text {e }}$ Department of Surgery, Prince of Wales Hospital, The Chinese University of Hong Kong, China \\ ${ }^{f}$ BioPharmaNet, Department of Biochemistry and Molecular Biology, The University of Ferrara, Italy
}

\section{Keywords}

Acetaminophen · Hepatic injury · N-Acetyl cysteine · Silymarin

\section{Summary}

Aim: Recently, we have demonstrated that silymarin has a comparable pharmaceutical activity as Phyllanthus urinaria extract when used to rescue mice from acetaminophen-induced acute liver injury. In the present study, we further compared the therapeutic action of silymarin with $\mathrm{N}$-acetyl cysteine (commonly used in clinical practice for emergency treatments) as a rescuer in mice after administering a lethal dose of acetaminophen for $24 \mathrm{~h}$. Methods: Acute liver injury was induced in the treatment groups by intraperitoneally administered acetaminophen at a dose of $550 \mathrm{mg} / \mathrm{kg}$ body weight on day 1 . The control group received an equal volume of physiological saline intraperitoneally. From day 2 to 4 , the treatment groups received various doses of silymarin or $\mathrm{N}$-acetyl cysteine orally once daily, while the control group and the acetaminophen group received an equal volume of water orally. The mortality rate was recorded in all groups. On day 5, all mice were sacrificed for examination. Results: Silymarin greatly improved the counteracting effects on mortality rate as compared to $\mathrm{N}$-acetyl cysteine. Conclusion: Silymarin should be further considered as an antidote for patients with acetaminopheninduced acute hepatic injury and delayed treatment.

\author{
Schlüsselwörter \\ Acetaminophen · Leberversagen · N-Acetylcystein • \\ Silymarin
}

\section{Zusammenfassung}

Ziel: Wir haben kürzlich gezeigt, dass Silymarin eine vergleichbare pharmazeutische Wirkung hat wie ein Extrakt aus Phyllantus urinaria. In einem Maus-Experiment waren beide Wirkstoffe bei der Therapie eines durch Paracetamol hervorgerufenen Leberversagens vergleichbar. In der vorliegenden Studie wurde die therapeutische Wirkung von Silymarin und N-Acetylcystein bei Mäusen, denen $24 \mathrm{~h}$ lang eine tödliche Dosis Paracetamol verabreicht wurde, verglichen. Methode: Am 1. Tag wurde in den Behandlungsgruppen akutes Leberversagen durch eine intraperitoneale Injektion von Paracetamol in einer Dosis von 550 mg/kg Körpergewicht erzeugt. Einer Kontrollgruppe wurde die gleiche Menge an physiologischer Kochsalzlösung verabreicht. Vom 2.-4. Tag wurden die Versuchsgruppen einmal täglich oral mit verschiedenen Dosen Silymarin oder N-Acetylcystein behandelt. Die Kontrollgruppe und die Paracetamol-Gruppe erhielten die entsprechende Menge Wasser. Die Überlebensrate wurde in allen Gruppen dokumentiert. Am 5. Tag wurden alle überlebenden Mäuse getötet und die Veränderungen der Leber untersucht. Ergebnisse: Silymarin war im Vergleich zu N-Acetylcystein von bedeutendem Vorteil. Die Überlebensrate konnte mit Silymarin verbessert werden. Schlussfolgerung: Silymarin könnte als Antidot für Patienten mit Paracetamol-induziertem akutem Leberversagen, wenn sich eine initiale Behandlung verzögert, in Zukunft von größerem Interesse sein.

\begin{tabular}{ll}
\hline KARGER & $\oplus 2010$ S. Karger GmbH, Freiburg \\
Fax +497614520714 & Accessible online at: \\
$\begin{array}{l}\text { Information@Karger.de } \\
\text { www.karger.com }\end{array}$ & www.karger.com/fok
\end{tabular}




\section{Introduction}

An overdose of acetaminophen (APAP) is one of the common types of drug poisoning. It can lead to fatal damage of vital organs including liver, heart, and kidneys. An overdose of about $10 \mathrm{~g} / \mathrm{kg}$ body weight (BW) can be fatal, as liver damage may develop after several hours of intake. The culprits are found to be the oxidative products of APAP including $\mathrm{N}$-acetyl-benzoquinone imine. Such oxidative metabolites may completely reduce the intracellular glutathione and thus damage hepatocytes [1].

Recently, we have conducted experiments aimed to explore the hepatoprotective activity of Phyllanthus urinaria $(P$. urinaria) in a mice model $24 \mathrm{~h}$ after administering a lethal dose of APAP $(550 \mathrm{mg} / \mathrm{kg} \mathrm{BW})$. This APAP dosage causes in C57B16 mice a very poor prognosis: the majority of the mice did not survive for 3 days. The experimental model employed mimics a clinical condition similar to that found in patients admitted to the accident and emergency divisions of hospitals with acute liver toxicity. We have shown that $P$. urinaria extract may protect hepatocytes from APAPinduced necrosis after delayed therapy [2]. In the same article we have also shown that silymarin could yield similar survival rates as $P$. urinaria extract. In the present study, we compare the therapeutic action of silymarin with that of $\mathrm{N}$-acetyl cysteine (NAC) (which is commonly used in clinical practice for emergency treatment) as a rescuer in mice after administration of a lethal dose of APAP for $24 \mathrm{~h}$. In addition to comparing the mortality rate, we analyzed the possible occurrence of necrotic features in a biopsy of liver section as well as liver function enzymes in the peripheral circulation.

\section{Materials and Methods}

\section{Chemicals and Reagents}

Unless otherwise stated, all reagents, including APAP, were purchased from Sigma chemicals. The physiological saline for APAP injection was obtained from Baxter. NAC was obtained from Zambon (Switzerland).

\section{Animal Care}

8-week-old C57B16 mice, weighing approximately 20-25 g, were purchased from the animal unit of The Chinese University of Hong Kong and maintained in a conventional sanitary facility, in accordance with the institutional guidelines on animal care, with the required consistent temperature and relative humidity. All procedures were approved by the Animal Research Ethics Committee.

\section{APAP Treatment on Mice}

APAP was dissolved in physiological saline. A total of 25 mice were included in the study. On day 1 , acute liver injury was induced by intraperitoneally administered APAP at a dose of $550 \mathrm{mg} / \mathrm{kg} \mathrm{BW}$ in 4 groups of mice. A control group of 3 mice was given intraperitoneally equal volumes of physiological saline. From day 2 to 4 , treatment groups received various doses of silymarin (100 or $200 \mathrm{mg} / \mathrm{kg} \mathrm{BW}$ ) or NAC orally once daily, while the control group and the APAP group received equal volumes of water orally (table 1). The treatment dosages of silymarin and NAC were based on the references [2] and [3], respectively. The mortality rate in each group was monitored and recorded. On day 5, all surviving mice were sacrificed for examination.

\section{Proposal for Histopathologic Examination and Biochemical Evaluation of Liver Injury}

Sections of mouse liver from autopsy samples were dewaxed, washed with phosphate buffered saline and then stained with hematoxylin and eosin ( $\mathrm{H}$ and $\mathrm{E}$ ) for nucleus and cytoplasm staining using the conventional protocol reported elsewhere. Slides were then premounted and inspected under a light microscope.

Whole blood was collected after the mice were sacrificed and plasma was isolated after centrifugation. Afterwards, plasma liver enzymes including alanine aminotransferase (ALT) and asparate aminotransferase (AST) were measured by the Vet biochemistry assay kits for the IDEXX laboratories machine in order to determine whether there were symptoms of liver failure in the silymarin-treated groups and in the control group.

\section{Results}

\section{Silymarin Inhibits APAP Induced Hepatotoxicity in vivo}

NAC administered at $200 \mathrm{mg} / \mathrm{kg} \mathrm{BW}$ per day was found to be helpless in APAP overdose-treated mice if treatment was delayed by 24 h. Only 1 out of 6 mice survived until day 3, dieing anyhow on the morning of day 4 (table 2). The mortality rate was more or less similar to that in the APAP group. If mice treated with APAP received orally administered silymarin, a significant improvement of the survival rate was observed (table 2) as compared to NAC. If the daily dose of sily-

Table 1. Experimental design to study the therapeutic potential of silymarin and NAC on mice after administration of an overdose of APAP and delayed therapy

\begin{tabular}{lll}
\hline Study group & Mice, $\mathrm{n}$ & $\begin{array}{l}\text { APAP } \\
\text { pretreatment }\end{array}$ \\
\hline Control group & 3 & no \\
APAP group $(550 \mathrm{mg} / \mathrm{kg} \mathrm{BW})$ & 4 & yes \\
NAC group $(200 \mathrm{mg} / \mathrm{kg} \mathrm{BW})$ & 6 & yes \\
Silymarin group 1 $(100 \mathrm{mg} / \mathrm{kg} \mathrm{BW})$ & 6 & yes \\
Silymarin group 2 $(200 \mathrm{mg} / \mathrm{kg} \mathrm{BW})$ & 6 & yes \\
\hline
\end{tabular}

Table 2. Survival percentage of mice treated with APAP alone (on day 1), NAC (single dose daily from day 2-4), and two different doses of silymarin (single dose daily from day 2-4)

\begin{tabular}{lllllrr}
\hline Study group & Mice, $\mathrm{n}$ & Day 1 & Day 2 & Day 3 & Day 4 & Day 5 \\
\hline APAP group $(550 \mathrm{mg} / \mathrm{kg} \mathrm{BW})$ & 4 & 100 & 100 & 25 & 0 & 0 \\
NAC group (200 mg/kg BW) & 6 & 100 & 100 & 16 & 0 & 0 \\
Silymarin group 1 (100 mg/kg BW) & 6 & 100 & 100 & 100 & 100 & 100 \\
Silymarin group 2 (200 mg/kg BW) & 6 & 100 & 100 & 100 & 100 & 100 \\
\hline
\end{tabular}


Fig. 1. $\mathrm{H}$ and $\mathrm{E}$ histochemical analysis of liver sections from 6 mice treated with a single dose of $550 \mathrm{mg} / \mathrm{kg} \mathrm{BW}$ of APAP followed by $200 \mathrm{mg} / \mathrm{kg}$ BW of silymarin for 3 days. Notice that 4 of 6 the liver sections exhibit necrosis, only the upper left and the lower right sections show a certain degree of cellular integrity (indicated by arrows). Representative photomicrographs from animal models are shown.
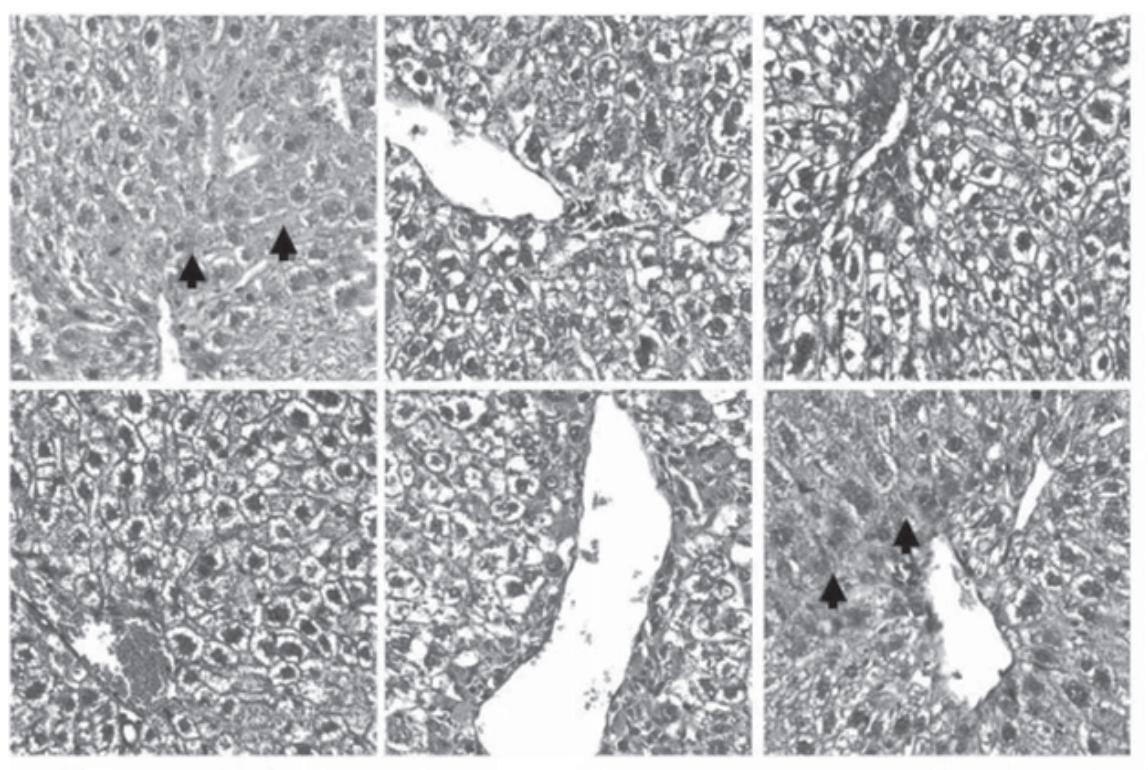

Magnification: $200 \mathrm{X}$
Fig. 2. $\mathrm{H}$ and $\mathrm{E}$ histochemical analysis of liver sections from 6 mice treated with a single dose of $550 \mathrm{mg} / \mathrm{kg}$ BW of APAP followed by $100 \mathrm{mg} / \mathrm{kg}$ BW of silymarin for 3 days. Representative photomicrographs from animal models are shown. Notice that all the liver sections exhibit necrosis.
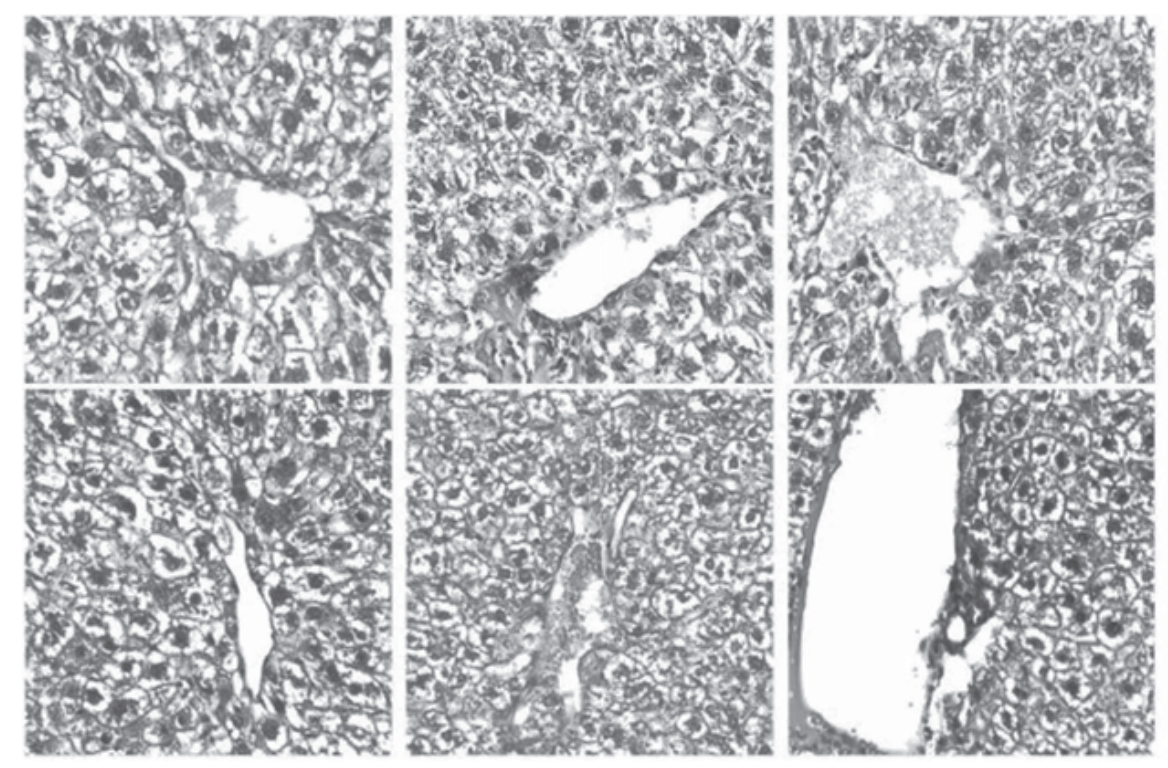

Magnification: $200 \mathrm{X}$ marin was increased from 100 to $200 \mathrm{mg} / \mathrm{kg} \mathrm{BW}$, liver autopsies revealed cytoplasm integrity of the hepatocytes in 2 of the 6 mice from the respective group (fig. 1). For the $100 \mathrm{mg} / \mathrm{kg}$ BW silymarin-treated group, all biopsy specimens exhibited necrotic liver feature (fig. 2). No histopathologic examination was performed for both the APAP and the NAC treatment group because the animals died before the end of the study.

\section{Plasma Liver Enzymes Test}

Liver function enzymes including ALT and AST in the plasma were analyzed in all mice of the control group and the silymarin-treated groups. It was found that both markers of liver function in the $100 \mathrm{mg} / \mathrm{kg} \mathrm{BW}$ silymarin-treated group were noticeably higher than in the control group. However, in the control group and in the $200 \mathrm{mg} / \mathrm{kg} \mathrm{BW}$ silymarin group they were similar (table 3). For the APAP and the NAC group no biochemical analyses were performed, as the animals had died before the end of the study.

\section{Discussion}

In clinical practice, NAC is the antidote of choice in cases of APAP overdose. It has been reported from clinical practice that NAC given within $8 \mathrm{~h}$ of APAP ingestion has a protective effect regardless of initial plasma APAP concentrations. 
Table 3. Plasma liver functional assays from mice treated with APAP (single dose of $550 \mathrm{mg} / \mathrm{kg}$ BW on day 1) and 2 different doses of silymarin (single dose daily from day 2-4). Student's t test was used and data was considered to be statistically significant when $\mathrm{p}<0.05$. No statistically significant difference was found between the APAP and the two silymarin treatment groups $(\mathrm{p}>0.05)$.

\begin{tabular}{llll}
\hline & Control group & $\begin{array}{l}\text { Silymarin } \\
100 \mathrm{mg} / \mathrm{kg} \mathrm{BW}\end{array}$ & $\begin{array}{l}\text { Silymarin } \\
200 \mathrm{mg} / \mathrm{kg} \mathrm{BW}\end{array}$ \\
\hline ALT & $51.1 \pm 9.6$ & $79.8 \pm 12.4$ & $63.2 \pm 12.8$ \\
AST & $66.9 \pm 5.4$ & $96.5 \pm 30.7$ & $57.8 \pm 14.3$ \\
\hline
\end{tabular}

However, efficacy of NAC treatment was found to be significantly decreased if it was delayed further. It was concluded that NAC therapy should be started within $8 \mathrm{~h}$ after an APAP overdose; despite this limitation, the treatment is currently still indicated at least as late as $24 \mathrm{~h}$ after ingestion. It has also been noticed that delayed NAC administration after APAP intoxication significantly increases the risk of mortality [4].

Silymarin is a collection of complex flavonoids found in milk thistle and has been shown to increase liver glutathione levels in rats [5]. Milk thistle is recommended clinically as a supplementation for people who take acetaminophen in large doses for $>1$ year and/or with other risk factors for liver problems. The 'antidote' activity of silymarin has been demonstrated in many in vitro and in vivo models, including its protective effect against the strongest poison phalloidine [6]. Silymarin injected at a dose of $100 \mathrm{mg} / \mathrm{kg} \mathrm{BW} 10 \mathrm{~min}$ after phalloidine could provide a total protection of the experimental animals. However, as the time span between administration of phalloidine and start of treatment increased, the therapeutic activity of silymarin decreased as well, and after $30 \mathrm{~min}$ its 'antidote' effect was negligible. Silymarin has also been shown to be active in the treatment of hepatotoxicity [7, 8]. In the study presented here, we compared the therapeutic action of silymarin and NAC as an antidote in mice after administering a lethal dose of APAP for $24 \mathrm{~h}$. In the mouse, maximal toxicity following APAP occurred after approximately $6-8 \mathrm{~h}$. As maximal toxicity occurred so early, the antidote administered after $24 \mathrm{~h}$ had no effect on the development of toxicity. Our results have clearly demonstrated that treatment using NAC alone was not effective: the mortality rate was $100 \%$, i.e. the same as in the APAP group. NAC thus had no effect in terms of preventing lethality under our experimental design. Silymarin, in contrast, has been demonstrated to be highly effective. In fact, both the $100 \mathrm{mg} / \mathrm{kg} \mathrm{BW}$ and the $200 \mathrm{mg} / \mathrm{kg} \mathrm{BW}$ treatment of silymarin produced a $100 \%$ survival rate.
What we still have to discuss are the histochemical findings from the liver section autopsy and serum liver enzyme levels. In the present study, we presented the histopathological data with special focus on the centrilobular area because APAPinduced hepatotoxicity is pathologically characterized by its centrilobular hepatic necrotic features. In both silymarintreated groups, most of the APAP-treated mice showed observable necrotic features of their liver in $\mathrm{H}$ and $\mathrm{E}$ histochemical staining samples $(100 \%$ of the $100 \mathrm{mg} / \mathrm{kg} \mathrm{BW}$ and $66 \%$ of the $200 \mathrm{mg} / \mathrm{kg} \mathrm{BW}$ silymarin treatment groups). The mean plasma ALT and AST in the $100 \mathrm{mg} / \mathrm{kg}$ BW silymarin group were also considerably higher than in the control group. However, these plasma liver enzyme markers were comparable to those of the control group if the $200 \mathrm{mg} / \mathrm{kg} \mathrm{BW}$ silymarin group was considered.

Other experiments on animals have shown that the combination of NAC and cimetidine (an H2-receptor-antagonist drug and an inhibitor of hepatic microsomal oxidative enzymes) might also have an additive effect in the treatment of APAP overdose: in mice, the concomitant administration of NAC and cimetidine resulted in a zero mortality rate and significantly raised hepatic glutathione concentrations to values comparable to those of a saline-treated control group [9]. Similarly, co-administration of silybinin (a component of silymarin), cimetidine, and NAC, 30 min after APAP administration, was reported to be an effective antidote combination in a rabbit demonstration model [10]. Accordingly, we assume that a concomitant administration of NAC and silymarin may be an effective antidote for the treatment of subjects with delayed therapy after APAP overdose.

We assume that, in the future, silymarin extract can be used as a complementary medicine in the emergency treatment of APAP overdose with delayed therapy provided further preclinical and clinical data will support our hypothesis.

\section{Acknowledgments}

We acknowledge the financial support from the Haematology research funding offered by Professor GY-M Cheng and Dr. RS-M Wong, Chinese University of Hong Kong to Dr. C-H Chui, and a postgraduate research fund to Mr. DK-P Hau from The Baptist University of Hong Kong (4040-173 RDD Development Fund). Professor R. Gambari is sponsored by AIRC (Italian Association for Cancer Research). Lastly, Mr. DK-P Hau would like to thank the supervision from Professor DW-F Fong.

\section{Conflict of Interest}

None. 


\section{References}

1 Kelly GS: Clinical application of N-acetyl cysteine. Altern Med Rev 1998;3:114-127.

2 Hau DKP, Gambari R, Wong RSM, et al: Phyllanthus urinaria extract attenuates acetaminophen induced hepatotoxicity: Involvement of cytochrome P450 CYP2E1. Phytomedicine 2009;16:751-760.

3 Smilkstein MJ, Knapp GL, Kulig KW, Rumack BH: Efficacy of oral N-acetylcysteine in the treatment of acetaminophen overdose. Analysis of the national multicenter tudy (1976 to 1985). N Engl J Med 1998;319:1557-1562.

4 Wang PH, Yang MJ, Lee WL: Acetaminophen poisoning in late pregnancy. A case report. J Reprod Med 1997;42:367-371.
5 Valenzuela A, Aspillaga M, Vial S, Guerra R: Selectivity of silymarin on the increase of the glutathione content in different tissues of the rat. Planta Med 1989;55:420-2.

6 Desplaces A, Choppin J, Vogel G, Trost W: The effects of silymarin on experimental phalloidine poisoning. Arzneimittelforschung 1975;25:89-96.

7 Asha VV, Akhila S, Wills PJ, Subramoniam A: Further studies on the antihepatotoxicity activity of Phyllanthus maderaspatensis Linn. J Ethnopharmacol 2004;92:67-70.
8 Rajkapoor B, Venugopaly Y, Anbu J: Protective effect of Phyllanthus polyphyllus on acetaminophen induced hepatotoxicity in rats. Pak J Pharm Sci 2008;21:57-62.

9 Al-Mustafa ZH, Al-Ali AK, Qaw FS, Abdul-Cader $\mathrm{Z}$ : Cimetidine enhances the hepatoprotective action of $\mathrm{N}$-acetylcysteine in mice treated with toxic doses of paracetamol. Toxicology 1997;121:223-228.

10 Zira A, Mikros E, Giannioti K, et al: Acute liver acetaminophen toxicity in rabbits and the use of antidotes: a metabonomic approach in serum. J Appl Toxicol 2009;29:395-402. 